\title{
Effects of Socio-Cultural Developments of Gjakovar Society
}

\author{
Bekim AVDIAJ \\ PhD Cand. European University of Tirana, Social Sciences \\ Lumnije AVDIAJ
}

MSc on Economics, College "Biznesi"

\begin{abstract}
Human being is nowadays experiencing the highest achievements in all domains of life. These developments entered in almost all human societies, even to the most isolated ones. This has also influenced that today's societies differ significantly from the thousand-years-old traditional societies. Such radical transformations, did not only change the world outside, but they continue to change radically the most intimate aspects of personal daily life. These achievements on one hand represent great promises for the future, creating possibilities to access and communicate with the most remote places on the planet, while on the other hand these present security concerns. Part of these developments and transformations is also the Gjakovar society, which until this new century was distinguished for traditional and cultural organization, not only in Kosovo, but all over Albanian territories. However, the new flows of time development imposed the reorganization of society in this area. Certainly it had and continues to have its challenges, especially from its internal part. Transformation and the new developing flows dictated in weakening the secular traditions and cultural habits and embrace new ones. Although on one side it appears to be positive, on the other hand are emerging new concern occurrences that are creating volatility and organization instability, and putting the society of this region in crisis through socio-cultural aspect, especially in the field of internal security.
\end{abstract}

Keywords: flows, culture, transformation, occurrences

\section{Introduction}

All communities that are politically and economically interrelated can be considered to comprise a society. Characteristically, a society includes a comprehensive social system, members of which society share amongst themselves a common language and cultural tradition. ${ }^{1}$

In principle, all human beings share approximately common social traits and what differentiates them is their tradition and culture. Those are transmitted and influenced depending on the developments of the society. The recent social developments, affected by the most-recent technologies, have 'globalized' the world by providing the opportunity of access in all their countries. The individual will, by all means, be 'influenced' by such access and this will accordingly reflect in the society.

On the other hand, Kosovo and Gjakova society, during the last years of the last century and during the first decade of the current century, has experienced a developmental evolution. There were several factors that facilitated and imposed it. Firstly, forced expulsion from their homes, immigration to different world countries and their return; secondly, social organizing in a democratic system run by an international administration which consisted of people from countries of different cultures and civilizations; and thirdly, access to modern technologies. These were exactly the causes that the 'contemporary' has led to the new cultural 'incision' which has definitely had an impact on Gjakova society as well.

According to this concept, culture consists mainly of ideas transmitted from preceding generations and of ideas learned from the experience of living in group. Nevertheless, culture cannot begin and end on ideas of different natures; it must encompass other aspects of human life. The term most often used to include all these aspects is "socio-cultural system". It integrates different aspects of ways of living, which reciprocally affect each other. ${ }^{2}$

\footnotetext{
${ }^{1}$ Keesing, R., \& Strathern, A. (2007). Cultural Anthropology - A Contemporary Perspective: 33

${ }^{2}$ Dhima, A. (2013). Anthropology of Communication - Access to Albanian Reality:139 
Therefore, based on the aforementioned, it is perceived that the transmission of socio-cultures from generation to generation has been followed with novelties in this domain, regardless of the prevalence of the traditional aspect. However, 'new values with regards to the change and the past can differ greatly between different societies, and it can actually be an interesting factor that should be taken into consideration"1.

\section{The traditional in Gjakova society}

Referring to the numerous scientific researches and the discovery of abundant new artefacts, the ancientness of Albanian people and society is now evident. This, among the rest, reflects also from the rich culture that followed it through the societal developments. It even results that the ancient Albanian culture was among the first cultures in Europe. That culture was the basis of today's culture and that through an age-long continuity.

During the centuries-old history, social developments suffered so many changes that many of them deviated from their tradition and culture all the way to complete assimilation. With regard to Albanian tradition and culture, the renowned Hungarian Albanologist, Tallock, has also stated: "There is no other people in the Balkans, or the one of the New Greece, that can trace back the history of its tribe, based on genealogical order, from the ancient times to the present date, like the Albanian people"2.

A similar opinion is provided by Professor M. Pirraku, according to whom, "Social, historic and cultural development Albanian people, as it is known, has undergone through all the stages of development of human societies and, what is most important, according to renown Albanologists, this nation is autochthonous in the Balkans soil, at least since the history time; however, it cannot be a priori dismissed the opinion that they were even more ancient, from the Balkans Mediterranean Indo-European and Pelazgi antiquity. ${ }^{3}$

This transmission of traditions and autochthonous culture through the stages of history since the most ancient dusks and its survival was done because "education was entirely national" although "there were neither special-trained educators nor special educational institutions"4. Yet, this has not impeded the transmission from one generation to the other in a most fanatic manner. Culture was exactly the most powerful arm of Albanian society that challenged all the storms through history and managed to emerge as triumphant. The transmitted culture has even, in a way, substituted for the educational shortcomings as well as the state ones.

This is more supported by Professor Dhima, according to whom "The social way of learning of culture not only 'saves' the individual 'costs' of common learning but also the knowledge acquired from every generation may be transferred through life experience - therefore to be transmitted socially - to the succeeding generations. Through this process, the younger people in a society absorb the culture from the elder ones"5. Albanian society had experienced exactly this.

Therefore, the survival of Albanian people since the ancientness, according to Rago, appears in the following manner, "Described as if it were a survived and all-time present Arcadia, it was thought to be inhabited by primitive people, free and courageous, bearers of thousand-years-old invariable traditions codified by the Code of the Mountains, impacted by a hostile geographic environment and by archaic living conditions, forger of men's characters, their antique customs and inclinations"6.

Thus, the Albanian national customs and habits have had an important role in the process of integration of Albanian national culture, which were present since the ancient times to the present all through the development periods of Albanian society.

It can, therefore, be said that the Albanian culture, in a wide sense, "was in history a strong defence against assimilation, denationalization and complete extinction of Albanian nation from the face of the earth." ${ }^{7}$ Hence, it was the customs and habits that accompanied Albanian individual and society from birth, during the growing up stage all the way to the death,

\footnotetext{
${ }^{1}$ Raimi, S. (2009). Sociology:135

${ }^{2}$ Krasniqi, M. (2002). Our Ethnic Roots:133

3 Pirraku, M. (1989). Albanian National Culture until Prizren League:33

4 Beqja, H. (1987, year VIII (15), no. 1. ). Evolution of Family Education and Its Present Main Types, At: National Culture:36

5 Dhima, A. (2013). Anthropology of Communication - Access to Albanian Reality:140

${ }^{6}$ Rago, P. (2011). Tradition, Nationalism and Communism in Modern Albania:40-41

7 Pirraku, M. (1989). Albanian National Culture until Prizren League:115-116
} 
through which it was achieved to confront all the conquerors' pressures and appetites and the influence of their cultures. These very factors influenced this society to remain more reclusive and isolated. So, "the introvert character was strongly displayed in the Albanian national culture for a set of reasons. The necessity of resistance against the century-old occupations, in such circumstances the Albanian national culture remained as the main bearer, perhaps the only one, of the ethnic tradition - the tradition that is known for great durability, which is why they live long and it happens to be preserved as archaic elements even after the conditions in which they emerged are changed."1

Precisely owing to their societal isolation, the social traditions were preserved 'clean' since the ancient times. This isolation was not a phenomenon present only with the Albanian people, as "by facing external threats, some nations took the traditional conservativism and applied it as their shield for survival; it was a way of safeguarding their cultural and individual identity"2.

So, it was these cultural traditions that organized life in Albanian society also in the social aspect, be that when such organizing from the state was lacking, even after the state was formed. All this was organized through the social norms of the time. Some of such norms continued existing even after adoption of laws. In certain circumstances social norms, in the social aspect, even after the responsibility for social welfare was acquired by the state through institutions continued their existence in moral form and they were present wherever it was needed, starting from the individual, family and even in parts of the society. This has always been proven through the traditional Albanian humanity and hospitality, not only to each other but also towards the foreigners. Actually, fear of being 'disgraced' and 'punishment by the community' were more 'powerful' than punishment by law.

The way or organizing and functioning of this region were special. Quite often it was a role model of organizing of social life not only for the Albanian society. Patriarchal family was the form that prevailed in Gjakova, too, as it did the vast majority of Albanian society and it was organized based on customary laws. The occasional passers-by were amazed with the order, culture and traditions of this area, which were really typical, traditional and of the time. The population of this area preserved and cultivated 'fanatically' the handicrafts inherited from generations, at the same time following the developments of the time. Gjakova families are well known for preserving the handicrafts their predecessors which are nowadays expressed in their family names. Thus, there are now Gjakova families with their last names Sahatçija, Çarkagjjia, Tabaku, Furra, Kazazi, Baruti, Nallbani, Kamishi, etc.

A similar assessment is provided also by the author Rago, according to whom: "by having its roots in the values that are closely linked to the preservation of tribe and family, Albanianism appeared as a modern product of traditional notions entrenched throughout centuries and different form the idea of nation, which is characteristic for those years"3.

These 'flows' and 'changes' accompanied the society throughout generations. However, despite the social evolutions, every society preserved fanatically its own tradition and culture. Paragraph of these 'preservations' was also Gjakova society.

The very facts of its existence in its area and preservation of culture and language are evidence on the century-old antiquity of this population. Albanian and Gjakova culture are developed as autochthonous cultures and alongside the process of Indo-Europeanism. However, Gjakova area is known for its "untouched' preservation of its clean tradition and culture since its ethno genesis.

\section{Socio-cultural transformations and the effects}

History occurs through the continual and constant interlacement, unification of the present and the past. This constant and reciprocal interlacement, this ever repeatable transformation of the past into the present and of the present into the past, does not allow us to talk about "unchanged" and "preserved" tradition of Albanian culture since the old ages. ${ }^{4}$

The so-called globalization did not spare the cultural aspects either. Recent developments have enabled the individual to become acquainted with the world and different cultures, which in turn has enabled not only transmission through

\footnotetext{
${ }^{1}$ Çapajev, G. (1987, year VIII (16), no. 2.). National Culture in the Mentality of Renaissance Writers, At: National Culture:22-23

${ }^{2}$ Keesing, R., \& Strathern, A. (2007). Cultural Anthropology - A Contemporary Perspective:389

${ }^{3}$ Rago, P. (2011). Tradition, Nationalism and Communism in Modern Albania:19

${ }^{4}$ Bobi, G. (1986). Cultural Paradox:18 
generations but also embracing of part of foreign cultures. According to Professor A. Dhima, owing to this process, through which particular cultural elements or all the elements of a socio-cultural system are geographically spread out from one region or nation to the other, members of different societies are placed into direct or indirect contact to each other. But, at the same time some customs and beliefs are distributed from one society to another, which in turn carries the important consequence that the way of living of both interlaced societies in this process become more similar. We often hear that, in present time, the whole world is becoming modernized. In fact, nations more resemble each other at the present than one century ago. ${ }^{1}$

This is not something new, because since the formation of human society things have developed and changed, naturally depending on the circumstances of the time. Such a process was also declared by Heraclitus, out of which he has elicited his philosophical moto "panta rhei" - everything flows, everything changes and "we cannot go twice into the same river". ${ }^{2}$ Also, the opinion of evolution and progress is supported by a huge number of scholars starting from Durkheim all the way to Marx, Ferguson and Comte.

Although the documents are scares, at least until now, this does not present any obstacle for cultures because oftentimes they are not in written form but they are transmitted and transferred verbally from generation to generation within the group of the society, as is the typical case of this area. It is understandable that culture differs from one society to the other, but it also differs within the same society and that from one time period to another. Until lately although the past of the nations relied on 'transmission' and 'preservation' of cultural traditions through a variety of forms until 'isolation', it still had such 'intersection'. This is proven also by the anthropological cultural side, where almost all cultures of Balkans ethnicities even at the present inherit interceptions between them, by creating a special zone of this part of Europe which, unfortunately, is well known for its temperament and conflictual mentality.

Present societal developments, especially in the field of technology, have influenced that only a short time ago the enormous and 'unreachable' world has become today a 'very small' place and easily reachable. Among the rest, this has also had an impact not only on 'socio-cultural intersections' but it has also brought fundamental transformations in this direction.

Today, a continually growing number of people do not have clear racial or ethnic identities. These are people in the 'border' between different cultural groups. While they may feel split between different cultural traditions, they may also develop a multi-cultural identity - an identity that overcomes one specific culture - and they are comfortable in different cultures. ${ }^{3}$

Such a reality is also being lately experienced by the Albanian and Gjakova society, in particular upon the democratization of this society. "With the establishment of Albanian state the sense of self-sufficiency of Albanian culture is gradually falling down thus creating an onerous situation, a stress and internal tension which cannot be lowered within the national culture: orientations are being outside of it, overcoming of traditional values, however, is not being achieved due to ambivalent stance towards them; there are also backward movement, different forms of Albanians' socio-centrism are becoming apparent, ways are being opened to the social violence and ideological totalitarianism."4

With regards to the changes in the organization of Albanian social life, during this 'transitional' period, our Kosovo society is facing several problems. One of the problems appears to be the socio-cultural aspect which is connected to a complicated process of 're-assessment of values', without which it is impossible for a society to function, no matter how modern that society is. ${ }^{5}$

It is quite understandable that things change in time, especially the socio-cultural ones and regardless of how much they have reflected with time, yet again a more advanced society cannot be built only upon them, even less when we have to deal with modern organization of society, as is the case with Kosovo and Gjakova society.

\footnotetext{
${ }^{1}$ Dhima, A. (2013). Anthropology of Communication - Access to Albanian Reality:140-141

${ }^{2}$ Raimi, S. (2009). Sociology:252

3 Martin, N. J., \& Nakayama, K. T. (2010). Entry into Inter-Cultural Comunication:134

${ }^{4}$ Bobi, G. (1986). Cultural Paradox:166-167

5 Tushi, G. (2006). Social Problems and Dilemmas:13
} 
"In this context, our society is experiencing another 'identity crisis' which has to do with the re-dimensioning of moral values and traditional social institutions. These changes have had an impact on moral concepts, values and institutions of traditional 'moral security' of the society, such as: society, religion, family, marriage, individual, community, etc."1

From the main causes of social unrests is also the truth that by opposing traditional structure, the very tradition is opposed, various cultural elements are being judged, customs and habits which are contained within the tradition. However, just as the negation, refusal and blaming of tradition in its entirety is wrong, it is also wrong the full acceptance of the same as it is; because tradition cannot form itself through its own specific laws since in its formation an important role play different historical and social factors. It can be said that regardless of the type of tradition, every tradition carries in itself traces of the past, of the location where such tradition was spread out. ${ }^{2}$

Whilst Gjakova society, just like other post-communist countries, is undergoing a multiple transitional process, such as: political transition from one party to multi-party system, economical transition from one planned economy to a trade economy, transition in the field of security of the country into the international security, this does not spare the socio-cultural transition.

Referring to the real circumstances in which the democratic organizing of Kosovo society begins, especially Gjakova society bearing in mind the difficult conditions, the presence of difficulties during this process was inevitable. Therefore, this society 'entered the path of transition at a time where there was no independent judiciary, free media and independent civil groups and associations". And "during the initial phase of transition it remained unprotected of dangerous and unstable currents that came from abroad."

Thus, Gjakova society during its journey to the 'contemporary' that is in the transition from the closed-type model into the 'open' type was accompanied by different challenges, especially in the socio-cultural field. These difficulties are emphasized also by G. Tushi, who says: In this process of transition, the sphere of social transformation of concepts, taboos, judgments and prejudice of the past have been and continues to remain more difficult, because, as it is known, because of their specific inertness and the stable conservator core, social changes are more difficult to change with the required rhythm. Our experience has even proven that in often cases when they do occur, they create a "social vacuum"4.

Our society is suffering a fast change and accordingly it is losing the cycle of giving and returning, which is ensured by the cycle of life and is oftentimes found in the moral system of some people; parents that look after their children when they are small and have no assistance can be looked after by their children when they grow old and will be needing help. ${ }^{5}$ Nowadays the 'cycle of return' has almost completely vanished, despite the fact that it had been contributed to in the past. In Albanian and Gjakova society the cycle of giving and returning was in the highest social level. Regardless of life conditions of the individual, from the social aspect point of view, his being was not endangered because even if he had no children and no family, other relatives would look after him to the last moments of his life as well as for the burial ceremony. Whereas nowadays the 'contemporary' has brought in new circumstances in the Albanian and in Gjakova society, as well. The 'return' cycle in the social aspect does not function here either, except in some rare cases due to moral and humanitarian reasons. This is proven by numerous social cases present in this society. There are such cases that although the family enjoys good living conditions, even the immediate family, and the elderly are left alone and in the mercy of fate. Sometimes the return 'cycle' is used to accommodate them in asylums, but there are also cases that after some time they have been found dead while they were completely alone.

Professor Dhima is right to ascertain that "In case quick or unforeseen changes occur in the way of living between generations, then a 'cultural vacuum' can be created, in the sense that new generation does not accept or consciously rejects some elements of their parents' culture. In certain conditions and circumstances, this occurrence may spread widely within the members of the same society which belong to different generations. At present time, in most of the western developed societies, the young quite often believe that they have very few common things with their parents; but the latter

\footnotetext{
${ }^{1}$ Tushi, G. (2006). Social Problems and Dilemmas:13

${ }^{2}$ Bullaç, A. (2003). History, Society and Tradition:283-284

3 Biberaj, E. (2011). Albanian in Transition - The Hard Path to Democracy 1990-2010:30

4 Tushi, G. (2006). Social Problems and Dilemmas:12

${ }^{5}$ Keesing, R., \& Strathern, A. (2007). Cultural Anthropology - A Contemporary Perspective:294
} 
also blame the young generation for "low standards", e.g. in the sphere of sexual morality. However, the cultural "fissures" between generations of a certain society - even when noticeable - are unimportant compared to those that are observed between the socio-cultural systems of different nations. ${ }^{1}$

Such a cultural 'vacuum' is at the present time being experienced by Gjakova society when actually the young have 'embraced' many of the global cultures and their behaviour visa-vi the family, environment and the society are outside the traditional 'parameters'. Moreover, such 'flow' has created a disharmony not only in the society but also in the family.

This finding is proven by the statistics of the offences reported with the security authorities where it really results that alongside the new 'flow' in the aspect of 'modernizing' and 'contemporary' we also have the occurrence of new offences which have not been present in the past in the society of this region. Some of the new occurrences were even not sanctioned by laws, but they have been sanctioned afterwards and continue being sanctioned depending on the new trend of appearance of the occurrences which infringe the social order. Even those that existed in the past were few in number; whereas, today they present a serious concern for the whole society.

Table 1. Statistics table on some of criminal offences reported from 1999 to 2012, as per regional division in Gjakova and its surrounding

\begin{tabular}{|l|l|l|l|l|l|}
\hline Offence & Gjakova & $\begin{array}{l}\text { Hasi } \\
\text { Region }\end{array}$ & $\begin{array}{l}\text { Dushkaja } \\
\text { Region }\end{array}$ & Reka e Keqe Region & Total \\
\hline Suicide & 30 & 8 & 12 & 5 & 55 \\
\hline Attempted Suicide & & & & & 181 \\
\hline $\begin{array}{l}\text { Drugs \& psychotropic } \\
\text { substances }\end{array}$ & 84 & 4 & 5 & 7 & 100 \\
\hline Domestic Violence & 142 & 13 & 22 & 15 & 192 \\
\hline Trafficking in Human Beings & 16 & 1 & 1 & 6 & 24 \\
\hline Missing Persons & 125 & 15 & 15 & 17 & 172 \\
\hline Usurpation of Property & 13 & & 2 & 1 & 16 \\
\hline $\begin{array}{l}\text { Illegal Entry into Computer } \\
\text { System }\end{array}$ & 4 & & & 1 & 5 \\
\hline
\end{tabular}

With reference to these statistics, the assessment of G. Tushi results as a right one, according to whom: "The extended space of freedom of individual and ever higher independence from the rules and collective social and moral obligations, acceptable and consensual, is being accompanied by the appearance of new phenomena, unknown in the past. Freedom has its social cost; it has its consequences and deformations that result from the incidents of modern life. Indeed, some horrible socio-political wounds have disappeared in our time, such as dictatorship, the monistic and determinist political and moral concept, the concept of personal privacy has been extended, but at the same time new occurrences, phenomena and social wounds appeared, which were unfamiliar in the past."

They prove that our society is facing many problems in the socio-cultural domain, which inevitably are interlinked with 'reforms' of social organizing. On one hand, barriers and 'disagreements' appear between 'old' generations and 'new' generations and, on the other hand, there is the presence of social conditions and benefits form 'dirty businesses' of various profiteers. Some of the 'new occurrences' that have reflected in new generations are: marriages for love and without

\footnotetext{
${ }^{1}$ Dhima, A. (2013). Anthropology of Communication - Access to Albanian Reality:140-141

2 Tushi, G. (2006). Social Problems and Dilemmas:17-18
} 
"matchmaker - mediator", which compared with the past has increased the number of divorces and social problems with both of the families; the extravagant way of dressing by the young ages of female sex, in many cases there are reported cases of domestic violence because some parents disagree with that or, in the worst scenario, there are cases of attempted suicide and suicide on both generations; excessive use of psychotropic substances by persons of young ages, trafficking in human beings and their employment in 'night' bars; use of most recent technologies in committing various criminal offences, etc.

With regard to these cultural 'achievements' which are being misused by a certain part of citizens, we also have the assessments obtained during a research in the field, who give the opinion on the new cultural 'flow' and criminal occurrences in this area, and they are as following:

This region, being well known for its pure Albanian tradition and culture, the recent trends of criminality fall within the cultural traditions of this area: $1=$ entirely, $2=$ some and $3=$ none

\begin{tabular}{|ll|l|l|l|l|}
\hline & & Frequency & Percent & Valid Percent & $\begin{array}{l}\text { Cumulative } \\
\text { Percent }\end{array}$ \\
\hline Valid & 1 & 52 & 9.5 & 9.8 & 9.8 \\
& 2 & 219 & 39.8 & 41.3 & 51.1 \\
& 3 & 259 & 47.1 & 48.9 & 100.0 \\
& Total & 530 & 96.4 & 100.0 & \\
Missing & System & 20 & 3.6 & & \\
Total & & 550 & 100.0 & & \\
\hline
\end{tabular}

In addition to numerous changes while transiting into the democratic system of our society, is there any evolvement in the appearance of new criminal occurrences which have not been met before in the tradition and culture of this region? $1=$ a lot, $2=$ little and $3=$ partially

\begin{tabular}{|ll|l|l|l|l|}
\hline & & Frequency & Percent & Valid Percent & $\begin{array}{l}\text { Cumulative } \\
\text { Percent }\end{array}$ \\
\hline Valid & 1 & 201 & 36.5 & 37.9 & 37.9 \\
& 2 & 184 & 33.5 & 34.7 & 72.6 \\
& 3 & 145 & 26.4 & 27.4 & 100.0 \\
& Total & 530 & 96.4 & 100.0 & \\
Missing & System & 20 & 3.6 & & \\
\hline
\end{tabular}


Referring to the answers on both questions excerpted from a questionnaire applied during a field research, it results that the recent trends of criminal occurrences in Gjakova region do not belong to the culture and tradition of this area and that we have an evolvement of these occurrences which were not present in the past.

Therefore, this trend of development and modernizing of culture in this region, besides positive progress things and advancement of society, has also brought the confrontation with some permanent 'risks' that are accompanying step after step and without sparing anything, the consequences of which fall on the very individual, family, the environment and the whole society. These consequences are also costly, regardless on whose 'back' they will fall.

Referring to the statistics and assessments mentioned above, it is obvious that the society of this area, apart from the 'contemporary' is also being challenged by 'oscillations' as negative effects. Hence, it is observed that cultural 'flow' have an impact on the social state and which is very concerning, because from day to day it is going towards 'embracement' of cultures that are not in the same pace with the reality of our society. This inevitably adds to insecurity.

Based on the circumstances that citizens of Gjakova and its surrounding have faced in the field of criminal activity during the period of time 1999-2012, you asses that we had a situation: $1=$ Worrisome and $2=$ Calm

\begin{tabular}{|ll|l|l|l|l|}
\hline & & Frequency & Percent & Valid Percent & Cumulative Percent \\
\hline Valid & 1 & 423 & 76.9 & 79.8 & 79.8 \\
& 2 & 107 & 19.5 & 20.2 & 100.0 \\
& Total & 530 & 96.4 & 100.0 & \\
Missing & System & 20 & 3.6 & & \\
Total & & 550 & 100.0 & & \\
\hline
\end{tabular}

So, after a decade and a half of darting transformation, our society has become almost "qualitatively different society" which has no longer a enough security, where the weak person shall be protected.

Problems and social needs are increasing on daily basis, which the local and central state institutions are not able to respond to at the required extent. Therefore, it has come to the point when this society continues on with the 'genius achievements' by not sparing the individual, family or the social environment.

\section{Conclusions}

Human society was accompanied by the developments of the time. Evolutions were also present which brought in fundamental changes within the same society. Albanian society in Gjakova region was no exception.

However, new transformations, especially the socio-cultural, brought completely different circumstances creating problems in this area and making it impossible for the man to evaluate what should be inherited and what should be thrown as useless.

In these processes of social transformation from traditional into 'contemporary', regardless of the fact if they are necessary, its effects were not lacking.

'Contemporary' societies are accompanied by variou cultures and subcultures and the more modern they become, the more is the possibility for them to be exposed to 'risks'. These risks come due to disagreement between generations and new occurrences which are oftentimes direct or indirect causes of deviant behaviour of individuals in the society and ending in criminality. Therefore, 'contemporary' brought here also progress and goods for the individual and society but on the other hand it also brought in occurrences which were not evident in the past. 
So in the society, the new socio-cultural order put on stage the independent man, stating that he could reach all and on the other hand appears to be lonely and possibly with the loss of identity.

This has caused the fading and vanishing of the family and social 'common' be that in moral aspect, humane and social and to make the individual emerge on the surface. There is no more that fear of 'punishment' by the community, the individual acts based on his own interests, regardless that they may be harmful to the society by opening way also to criminal activity. The processes this society is going through are as yet powerful to challenge such circumstances and confrontation with the new socio-cultural reality is not on the same pace with the reality of life in this area. These have precisely produced negative and harmful effects for the society, starting from the socio-economic and cultural aspect all the way to the appearance of criminal occurrences that are evident and increase the concerns of citizens. Whilst we have a fading of the role of the family, unstable marriages, new criminal occurrences and on the other hand while the readiness of institutions is not at the required level to respond to such requests and needs, the social 'crisis' shall not be absent.

Finally, 'new developments' has had an effect in the opening of societies, which through the global 'technology' have 'destroyed' the authentic cultures and traditions which were transmitted through generations in centuries, by changing them into 'mixed' traditions and cultures.

Although this area was known for the preservation of its traditions and culture, modern democratic organizing brought in new cultural 'flow' and it affected that these 'achievements' are also 'embraced' in this area. They have 'vibrated' the society, by bringing in many novelties in the socio-cultural life and 'crisis' in social stability.

\section{Recommendations}

The needs for social developments have been and are necessary also for the society of Gjakova citizens and its surrounding. However, they must be followed according to the circumstances of the reality and 'flows' that bring benefits to the society should be 'embraced'.

Strengthen the 'common' of the family and society because only that will fill in for the institutional shortcomings and will reduce the socio-economic and cultural problems.

Prevent the interest of the individual when it causes harm to family and society and have the collective interest emerge. This would in turn prevent the appearance of new criminal occurrences, such as drugs, prostitution, trafficking in human beings, etc.

Local and central state institutions should as soon as possible take their role and implement projects that are in the interest of the society, even through various organizations. This would aid in rehabilitation of individuals 'infected' with criminal occurrences.

\section{References:}

Beqja, H. (1987, year VIII (15), no. 1. ). Evolution of Family Educaiton and Its Presnet Main Types, At: National Culture. Tirana: Academy of Science of SPRA - Institute of National Culture.

Biberaj, E. (2011). Albanian in Transition - The Hard Path to Democracy 1990-2010. Tirana: AllS.

Bobi, G. (1986). Cultural Paradox. Prishtina: Rilindja.

Bullaç, A. (2003). History, Society and Tradition. Skopje: Logos-A.

Çapajev, G. (1987, year VIII (16), no. 2.). National Culture in the Mentality of Renaissance Writers, At: National Culture Tirana: Academy of Science of SPRA - Institute of National Culture.

Dhima, A. (2013). Anthropology of Communication - Access to Albanian Reality. Tirana: Kumi.

Keesing, R., \& Strathern, A. (2007). Cultural Anthropology - A Contemporary Perspective. Tirana: UFO Pres.

Krasniqi, M. (2002). Our Ethnic Roots. Prishtina: Dukagjini. 
Martin, N. J., \& Nakayama, K. T. (2010). Entry into Inter-Cultural Comunication. Tirana: UET Pres.

Pirraku, M. (1989). Albanian National Culture until Prizren League. Prishtinë: Institute of Albanology in Prishtina.

Rago, P. (2011). Tradition, Nationalism and Communism in Modern Albania, Tirana. Tirana: Dudaj.

Raimi, S. (2009). Sociology. Tetovë: State University of Tetovo.

Tushi, G. (2006). Social Problems and Dilemmas. Tirana: Dudaj. Tirana: Dudaj 